ALCHEMY Jurnal Penelitian Kimia

Laman resmi: https://jurnal.uns.ac.id/alchemy

\title{
Uji Aktivitas Antibakteri Ekstrak Sarang Lebah Hutan (Apis dorsata) terhadap Pertumbuhan Staphylococcus aureus, Escherichia coli dan Pseudomonas aeruginosa
}

\author{
Ika Prestianti $^{a^{*}}$, Maswati Baharuddin ${ }^{a}$, Sappewali Sappewali ${ }^{a}$ \\ ${ }^{a}$ Jurusan Kimia, Fakultas Sains dan Teknologi, Universitas Islam Negeri Alauddin Makassar, Jl. Sultan \\ Alauddin No. 36, Samata-Gowa \\ * Corresponding author \\ E-mail:bmaswati@gmail.com
}

DOI: 10.20961/alchemy.14.2.13028.314-322

Received 08 August 2017, Accepted 20 November 2017, Published Online 03 September 2018

\begin{abstract}
ABSTRAK
Penyakit infeksi akibat bakteri merupakan masalah serius dalam kesehatan. Antibakteri alami yang dapat digunakan untuk menghambat pertumbuhan bakteri yaitu sarang lebah hutan (Apis dorsata) terdiri propolis, kantong madu, kantong telur dan kantong pollen yang mengandung senyawa metabolit sekunder seperti flavonoid, tanin dan asam fenolat. Tujuan dari penelitian ini adalah megetahui aktivitas antibakteri ekstrak sarang lebah hutan dari setiap pelarut yang digunakan dan untuk mengetahui pengaruh konsentrasi ekstrak sarang lebah hutan terhadap pertumbuhan bakteri Staphylococcus aureus, Escherichia coli dan Pseudomonas aeruginosa. Pengujian antibakteri dilakukan dengan metode difusi kertas cakram dengan lama perendaman 1 jam kemudian diinkubasi selama 3 x 24 jam. Hasil penelitian menunjukkan bahwa aktivitas antibakteri ekstrak metanol sarang lebah memiliki aktivitas tertinggi pada bakteri E. coli yaitu 3,8 mm pada konsentrasi $8 \%$, ekstrak etil asetat sarang lebah pada bakteri $S$. aureus yaitu $3,72 \mathrm{~mm}$ pada konsentrasi $8 \%$ dan ekstrak n-heksan sarang lebah pada bakteri $E$. coli yaitu $16,1 \mathrm{~mm}$ pada konsentrasi $8 \%$. Pengaruh konsentrasi ekstrak yaitu semakin tinggi konsentrasi maka semakin besar pula daya hambat ekstrak terhadap pertumbuhan bakteri S. aureus, E. coli dan P. aeruginosa.
\end{abstract}

Kata kunci: aktivitas antibakteri, kantong madu, sarang lebah

\begin{abstract}
Antibacterial Evaluation of Extract Beehive (Apis dorsata) against Growth of Staphylococcus aureus, Escherichia coli and Pseudomonas aeruginosa. Bacterial infectious diseases are serious health problems. A natural antibacterial that can be used to inhibit bacterial growth of honeycomb (propolis, honey bag, egg bag and pollen bag) containing secondary metabolite compounds such as flavonoids, tannins and phenolic acids. The purpose of this research is to know the antibacterial activity of honeycomb extract from each solvent used and to know the effect of honeycomb extract concentration against the bacteria growth of Staphylococcus aureus, Escherichia coli and Pseudomonas aeruginosa. Antibacterial testing was performed by the method of paper disc diffusion with soaking time 1 hour followed by incubation for $3 \times 24$ hours. The results show that antibacterial activity of methanol honeycomb extract had the highest activity in $E$. coli bacteria of $3.8 \mathrm{~mm}$ at $8 \%$ concentration, followed by those of ethyl acetate honeycomb extract and $\mathrm{n}$-hexan honeycomb extract which have antibacterial activity of $3.72 \mathrm{~mm}$ and $16.1 \mathrm{~mm}$ at $8 \%$ concentration against $S$. aureus and E. coli, respectively. The effect of extract concentration is the higher the concentration the greater the inhibitory power of extract against the bacteria growth of $S$. aureus, E. coli and $P$. aeruginosa.
\end{abstract}


Keywords: antibacterial activity, beehive, E. coli, P. aeruginosa, S. aureus

\section{PENDAHULUAN}

Penyakit akibat infeksi bakteri merupakan masalah serius dalam kesehatan, selama beberapa tahun terakhir terjadi peningkatan timbulnya penyakit infeksi yang disebabkan oleh bakteri (Rizal et al., 2015). Beberapa bakteri yang dapat menimbulkan infeksi antara lain bakteri Staphylococcus aureus, Escherichia coli dan Pseudomonas aeruginosa. Staphylococcus aureus penyebab infeksi kulit (Lauma et al., 2015). Escherichia coli yang merupakan bakteri patogen penyebab infeksi diare akut. Pseudomonas aeruginosa menimbulkan infeksi pada luka dan luka bakar. Penyakit infeksi dapat diobati dengan menggunakan antibiotik (Sulistyaningsih et al., 2016).

Penggunaan obat antibiotik secara tidak tepat dapat menimbulkan kerugian yang luas dari segi ekonomi dan kesehatan. Hal ini dapat dihindari dengan memanfaatkan bahan alam sebagai obat tradisional yang dinilai memiliki efek samping lebih kecil dibandingkan dengan obat yang berasal dari bahan kimia, salah satu bahan alami yang dapat dimanfaatkan yaitu sarang lebah hutan (Apis dorsata). Zat pembentuk sarang lebah yaitu lilin lebah, lebah mengeluarkan lilin untuk membangun sarang tempat penyimpanan madu. Kekayaan sifat protektif hidrofobik pada lilin lebah sehingga digunakan dalam industri makanan, produk kosmetik dan film (Fratini et al., 2016). Pembentukan mikropron dalam film sangat besar pengaruhnya dari perbedaan pelarut (Wang et al., 2014).

Daerah Kolaka (Sulawesi, Indonesia) memiliki hutan yang cukup luas dan salah satu potensi hutan yang juga menjadi mata pencaharian masyarakat di sana yaitu mencari madu hutan yang dihasilkan oleh lebah Apis dorsata. Secara ilmiah, madu terbukti memiliki kandungan senyawa organik seperti asam fenolat dan flavonoid yang bersifat antibakteri (Sholihah, 2013). Menurut Rahman et al. (2010) pada aktivitas antibakteri madu dan propolis dengan menggunakan metode difusi cakram mampu menghambat bakteri $S$. aureus dan $E$. coli, propolis pada konsentrasi 2,74 sampai 3,5 dan 3,5 $\mathrm{mg} \mathrm{mL}^{-1}$ efektif untuk menghambat S. aureus dan E. coli. Sebaliknya, madu efektif untuk menghambat bakteri S. aureus pada konsentrasi $375,0 \mathrm{mg} \mathrm{ml}^{-1}$. Aktivitas antibakteri pada madu sangat baik terhadap isolat bakteri yang menunjukkan kegunaan madu dalam praktek klinis terhadap infeksi bakteri (Mandal et al., 2010).

Senyawa metabolit sekunder yang bersifat sebagai antibakteri tidak hanya diperoleh dari madu, bahkan sarang lebah dapat juga dijadikan sebagai sumber antibakteri. Kandungan senyawa flavonoid, asam fenolat dan tanin yang terdapat dalam sarang lebah dapat 
menghambat pertumbuhan bakteri gram positif maupun bakteri gram negatif (Yuliana et al., 2015). Kandungan alkaloid juga terdapat dalam pollen dan nektar dapat digunakan nikotin sebagai model senyawa dalam proses detoksifikasi dari sarang lebah madu terjadi peningkatan energetika pada respon antioksidan (Rand et al., 2015).

Aktivitas antibakteri ekstrak sarang lebah madu diencerkan (30\%) telah diuji terhadap dua strain bakteri yaitu gram-positif (S. aureus dan B. subtilis) dan satu gram negatif (E. Coli). Ekstrak metanol ditemukan dengan efek antimikroba terbaik terhadap S. aureus dengan zona hambatnya 1,15 mm (Naqvi et al., 2013). Hal ini mendukung peneliti untuk melakukan penelitian pada sarang lebah hutan dari daerah Kolaka untuk melihat aktivitas antibakteri terhadap dua jenis bakteri yaitu gram positif ( $S$. aureus) dan gram negatif (E. coli dan P. aeruginosa) dengan menggunakan pelarut yang berbeda.

\section{METODE PENELITIAN}

Alat-alat yang digunakan adalah sebagai berikut laminar air flow, autoklaf, vacum rotary evaporator, oven, neraca analitik, inkubator. Bahan yang digunakan adalah asam sulfat $\left(\mathrm{H}_{2} \mathrm{SO}_{4}\right)$ p.a,besi (III) klorida $\left(\mathrm{FeCl}_{3}\right) 5 \%$ dan $1 \%$, dimetilsulfoksida (DMSO), etil asetat $\left(\mathrm{C}_{4} \mathrm{H}_{8} \mathrm{O}_{2}\right)$, kertas cakram, kloramfenikol, isolat Escherichia coli ATCC 11229, isolat Pseudomonas aeruginosa ATCC 15442, isolat Staphylococcus aureus ATCC 6538, metanol $\left(\mathrm{CH}_{3} \mathrm{OH}\right)$, natrium klorida $(\mathrm{NaCl}) 0,9 \%$, n-heksan $\left(\mathrm{C}_{6} \mathrm{H}_{14}\right)$, nutrient agar $(\mathrm{NA})$ serta sarang lebah (propolis, kantong madu, kantong telur dan kantong pollen) dari Kolaka.

\section{Ekstraksi}

Sarang lebah diekstraksi dengan menggunakan metode maserasi. Sarang lebah dipotong-potong dan ditimbang masing-masing sebanyak 100 gram kemudian dimasukkan ke dalam 3 toples yang berbeda lalu ditambahkan dengan pelarut metanol pada wadah I, etil asetat pada wadah II dan n-heksan pada wadah III sampai sampel terendam kemudian ditutup dengan erat. Campuran sarang lebah yang sudah didiamkan selama 24 jam disaring dengan penyaring dan corong steril. Sisa ampas hasil saringan sarang lebah dimaserasi kembali sampai pelarut tidak berwarna dan filtrat hasil maserasi di uapkan dengan menggunakan evaporator pada suhu $45-50{ }^{\circ} \mathrm{C}$ hingga terbentuk ekstrak kental.

\section{Skrining Fitokimia}

Uji Kandungan Flavonoid

Ekstrak dipipet lalu diteteskan ke dalam plat tetes sebanyak 3 tetes kemudian ditambahkan dengan asam sulfat $\left(\mathrm{H}_{2} \mathrm{SO}_{4}\right)$ p.a sebanyak 1 tetes. Sampel positif mengandung 
flavonoid jika larutan mengalami perubahan warna yang sangat mencolok menjadi warna kuning, merah atau coklat (Munte et al., 2015).

Uji Kandungan Fenolik

Ekstrak dipipet lalu diteteskan ke dalam plat tetes sebanyak 3 tetes kemudian ditambahkan 2 tetes larutan besi (III) klorida $\left(\mathrm{FeCl}_{3}\right)$ 5\%. Sampel positif mengandung fenolik jika terbentuk warna hijau, hitam kebiruan atau hitam kuat (Putri and Hidajati, 2015). Uji Kandungan Tanin

Ekstrak dipipet lalu diteteskan ke dalam plat tetes sebanyak 3 tetes kemudian ditambahkan dengan besi (III) klorida $\left(\mathrm{FeCl}_{3}\right) 1 \%$ sebanyak 2 tetes. Sampel positif mengandung tanin jika larutan mengalami perubahan warna menjadi hijau kehitaman (Huliselan et al., 2015).

\section{Uji Aktivitas Antibakteri}

Biakan bakteri pada suspensi diambil sebanyak $500 \mu \mathrm{L}$ kemudian dituang ke dalam cawan petri steril dan media agar dituang ke dalam cawan petri steril yang berisi suspensi bakteri lalu dihomogenkan. Masing-masing ekstrak pada variasi $2 \times 10^{4} \mathrm{ppm}, 4 \times 10^{4} \mathrm{ppm}$, $6 \times 10^{4} \mathrm{ppm}, 8 \times 10^{4} \mathrm{ppm}$, kontrol positif dan kontrol negatif sebanyak $50 \mu \mathrm{L}$ diteteskan pada kertas cakram steril dan dibiarkan beberapa saat kemudian kertas cakram yang sudah kering diletakkan secara teratur di atas medium agar yang mengandung bakteri uji dan kemudian diberi label dan diinkubasi selama 3 x 24 jam pada suhu $37^{\circ} \mathrm{C}$, setiap 1 x 24 jam zona bening yang terbentuk diukur dengan jangka sorong. Sebagai kontrol positif digunakan kloramfenikol sedangkan kontrol negatif digunakan dimetilsulfoksida (DMSO).

\section{HASIL DAN PEMBAHASAN}

Berdasarkan penelitian hasil skrining fitokimia pada sampel sarang lebah dapat dilihat pada Tabel 1 .

Tabel 1. Hasil Uji Skrining Fitokimia Sarang Lebah.

\begin{tabular}{cccc}
\hline Ekstrak & \multicolumn{3}{c}{ Uji Pendahuluan } \\
\cline { 2 - 4 } & Flavonoid & Asam Fenolat & Tanin \\
\hline Metanol sarang lebah & + & + & + \\
Etil asetat sarang lebah & - & + & - \\
n-Heksan sarang lebah & - & + & - \\
\hline
\end{tabular}


Berdasarkan hasil penelitian yang ditunjukkan pada Tabel 1 diperoleh hasil positif pada ekstrak metanol sarang lebah mengandung senyawa flavonoid dan tanin, ekstrak etil asetat sarang lebah dan ekstrak n-heksan sarang lebah mengandung senyawa asam fenolat. Menurut Yuliana et al. (2015) yang menyatakan bahwa dalam sarang lebah terdapat kandungan senyawa aktif yaitu asam fenolat, flavonoid dan tanin. Kadar fenol dalam sarang lebah madu Trigona spp dalam sarang yaitu kantong polen $0 \%$, kantong madu $0,22 \%$, dan kantong telur $0,87 \%$. Kadar fenol tertinggi terdapat pada kantong telur. Hasil uji fenol dengan menggunakan HPLC menunjukkan bahwa kantong polen 0\%, namun pada uji GCMS menunjukkan bahwa senyawa fenol terkandung didalam kantong polen. Hal ini disebabkan karena pemisahan kantong polen dengan polen menggunakan air yang menyebabkan sebagian besar fenol ikut terlarut didalam air.

Aktivitas antibakteri pada penelitian ini diuji dengan menggunakan metode difusi cakram dengan prinsip kerjanya yaitu bahan uji dijenuhkan ke dalam kertas cakram. Data aktivitas penghambatan ekstrak terhadap bakteri S. aureus dapat dilihat pada Tabel 2.

Tabel 2. Data diameter zona hambat ekstrak terhadap bakteri $S$. aureus dengan diameter kertas cakram $5 \mathrm{~mm}$.

\begin{tabular}{lcccccc}
\hline & \multicolumn{6}{c}{ Diameter zona hambat (mm) } \\
\cline { 2 - 7 } \multicolumn{1}{c}{ Ekstrak } & $\begin{array}{c}8 \times 10^{4} \\
\mathrm{ppm}\end{array}$ & $\begin{array}{c}6 \times 10^{4} \\
\mathrm{ppm}\end{array}$ & $\begin{array}{c}4 \times 10^{4} \\
\mathrm{ppm}\end{array}$ & $\begin{array}{c}2 \times 10^{4} \\
\mathrm{ppm}\end{array}$ & $\begin{array}{c}\text { Kontrol } \\
\text { positif }\end{array}$ & $\begin{array}{c}\text { Kontrol } \\
\text { negatif }\end{array}$ \\
\hline Metanol sarang lebah & 2,64 & 2,32 & 1,30 & 0 & 18,06 & 0 \\
Etil asetat sarang lebah & 3,72 & 2,62 & 1,44 & 0,86 & 16,18 & 0 \\
n-heksan sarang lebah & 0 & 0 & 0 & 0 & 23,6 & 0 \\
\hline
\end{tabular}

Hasil pengukuran menunjukkan bahwa pada ekstrak metanol dan ekstrak etil asetat sarang lebah menunjukkan aktivitas antibakteri tertinggi pada konsentrasi $8 \times 10^{4} \mathrm{ppm}$, hal ini di duga pada konsentrasi tersebut kandungan antibakteri atau zat aktif dalam ekstrak mulai meningkat. Menurut Yuliana et al. (2015) pada ekstrak campuran keseluruhan sarang (mix) yang menggunakan pelarut alkohol $70 \%$ memiliki daya hambat terhadap bakteri $S$. aureus dengan luas zona bening sekitar $90 \mathrm{~mm}$. Ekstrak n-heksan tidak menunjukkan adanya aktivitas antibakteri, menurut penelitian Rizal et al. (2013) bahwa aktivitas antibakteri ekstrak n-heksan kurang efektif atau lemah terhadap bakteri S. aureus.

Data aktivitas penghambatan ekstrak terhadap bakteri E. Coli dapat dilihat pada Tabel 3. 
Tabel 3. Data diameter zona hambat ekstrak terhadap bakteri E. Coli dengan diameter kertas cakram $5 \mathrm{~mm}$.

\begin{tabular}{lcccccc}
\hline \multirow{2}{*}{ Ekstrak } & \multicolumn{6}{c}{ Diameter zona hambat (mm) } \\
\cline { 2 - 7 } & $\begin{array}{c}8 \times 10^{4} \\
\mathrm{ppm}\end{array}$ & $\begin{array}{c}6 \times 10^{4} \\
\mathrm{ppm}\end{array}$ & $\begin{array}{c}4 \times 10^{4} \\
\mathrm{ppm}\end{array}$ & $\begin{array}{c}2 \times 10^{4} \\
\mathrm{ppm}\end{array}$ & $\begin{array}{c}\text { Kontrol } \\
\text { positif }\end{array}$ & $\begin{array}{c}\text { Kontrol } \\
\text { negatif }\end{array}$ \\
\hline Metanol sarang lebah & 3,80 & 3,50 & 2,22 & 0 & 17,08 & 0 \\
Etil asetat sarang lebah & 2,98 & 2,26 & 1,24 & 0 & 16,32 & 0 \\
n-heksan sarang lebah & 16,1 & 13,68 & 10,66 & 5,70 & 18,10 & 0 \\
\hline
\end{tabular}

Hasil pengukuran menunjukkan bahwa aktivitas penghambatan ekstrak metanol, etil asetat dan n-heksan sarang lebah menunjukkan aktivitas antibakteri dan meningkat dengan bertambahnya konsentrasi. Menurut Fitriana (2013) yang menyatakan bahwa besarnya diameter daya hambat pertumbuhan bakteri berbanding lurus dengan konsentrasi ekstrak yang diberikan.

Data aktivitas penghambatan ekstrak terhadap bakteri $P$. aeruginosa dapat dilihat pada Tabel 4.

Tabel 4. Data diameter zona hambat ekstrak terhadap bakteri $P$. aeruginosa dengan diameter kertas cakram $5 \mathrm{~mm}$.

\begin{tabular}{lcccccc}
\hline & \multicolumn{6}{c}{ Diameter zona hambat (mm) } \\
\cline { 2 - 7 } Ekstrak & $\begin{array}{c}8 \times 10^{4} \\
\mathrm{ppm}\end{array}$ & $\begin{array}{c}6 \times 10^{4} \\
\mathrm{ppm}\end{array}$ & $\begin{array}{c}4 \times 10^{4} \\
\mathrm{ppm}\end{array}$ & $\begin{array}{c}2 \times 10^{4} \\
\mathrm{ppm}\end{array}$ & $\begin{array}{c}\text { Kontrol } \\
\text { positif }\end{array}$ & $\begin{array}{c}\text { Kontrol } \\
\text { negatif }\end{array}$ \\
\hline Metanol sarang lebah & 0 & 0 & 0 & 0 & 19,72 & 0 \\
Etil asetat sarang lebah & 3,62 & 2,22 & 2,02 & 0,06 & 16,00 & 0 \\
n-heksan sarang lebah & 8,28 & 7,40 & 6,20 & 5,38 & 18,42 & 0 \\
\hline
\end{tabular}

Hasil pengukuran menunjukkan bahwa aktivitas penghambatan ekstrak metanol sarang tidak menunjukkan aktivitas antibakteri yang diduga kandungan zat antibakteri pada ekstrak tersebut hanya sedikit. Sedangkan pada ekstrak etil asetat dan n-heksan sarang menunjukkan aktivitas penghambatan, menurut Yuliana et al. (2015) bahwa pada ekstrak campuran keseluruhan sarang (mix) memiliki daya hambat terhadap bakteri P. aeruginosa.

Secara keseluruhan dapat diketahui bahwa diameter zona hambat yang terbentuk memiliki perbedaan variasi zona hambat, hal ini dapat disebabkan oleh beberapa faktor diantaranya lama inkubasi, konsentrasi ekstrak dan daya hambat zat yang berkhasiat sebagai antibakteri. Penelitian ini menggunakan kontrol positif kloramfenikol $1 \%$ yang memiliki 
spektrum luas terhadap bakteri gram positif dan gram negatif dan bersifat bakteriostatik. Menurut Brehm-Stecher and Johnson (2003) dalam metode difusi agar dengan konsentrasi $(0,5-2 \mathrm{mM})$ pada nerolidol, bisabolol atau apritone meningkatkan kerentanan bakteri $S$. aureus terhadap gentamisin, sedangkan pada bakteri E. coli sensitif terhadap nerolidol dan farnesol menjadi polymyxin B.

Daya hambat yang dihasilkan dari ketiga ekstrak tersebut memiliki perbedaan zona hambat yang berbeda terhadap ketiga jenis bakteri, daya hambat yang tergolong kuat diperoleh dari ekstrak n-heksan sarang lebah pada bakteri E. coli yaitu 16,10 mm. Menurut Davis and Stout (1971, dalam Ngajow et al., 2013: 132) bahwa ketentuan antibakteri yaitu daerah hambatan $20 \mathrm{~mm}$ atau lebih berarti sangat kuat, daerah hambatan 10 sampai $20 \mathrm{~mm}$ berarti kuat, 5 sampai $10 \mathrm{~mm}$ berarti sedang dan daerah hambatan $5 \mathrm{~mm}$ atau kurang berarti lemah.

Hasil pengukuran keseluruhan sarang lebah dari Kolaka berpengaruh terhadap pertumbuhan bakteri uji yaitu $S$. aureus, E. coli dan $P$. aeruginosa. Hal ini sesuai dengan penelitian Yuliana et al. (2015) bahwa hasil analisis statistika menunjukkan sarang lebah dari Lombok berpengaruh terhadap pertumbuhan mikrobia uji (S. aureus, P. aeruginosa, dan C. albicans). Berdasarkan data yang diperoleh untuk ekstrak metanol sarang lebah memiliki daya hambat antibakteri yang paling bagus, hal tersebut dikarenakan sampel ekstrak metanol sarang lebah dapat menghambat ke tiga jenis bakteri uji dan daya hambat yang diperoleh meningkat seiring naiknya konsentrasi dan berdasarkan hasil uji pendahuluan ekstrak metanol sarang lebah diduga mengandung senyawa metabolit sekunder yang lebih banyak yaitu flavonoid, asam fenolat dan tanin yang mampu menghambat pertumbuhan bakteri.

Flavonoid dapat menghambat pertumbuhan bakteri dengan cara merusak dinding sel dari bakteri, dengan terganggunya dinding sel akan menyebabkan lisis pada sel. Senyawa flavonoid berperan dalam perusakan fosfolipid pada membran sitoplasma bakteri, ion $\mathrm{H}^{+}$ dari flavonoid akan menyerang gugus polar (gugus fosfat) sehingga molekulfosfolipid akan terurai menjadi gliserol, asam karboksilat dan asam fosfat. Hal ini mengakibatkan fosfolipid tidak mampu mempertahankan bentuk membran sitoplasma, akibatnya membran sitoplasma akan bocor dan zat-zat untuk metabolisme sel bakteri akan terbuang keluar hingga bakteri akan mati (Agustina 2007, dalam Lutpiatina, 2015).

Mekanisme penghambatan senyawa fenolat pada mikroorganisme di karenakan oleh gangguan pada membran sel dan sintesis komponen struktural bakteri.Aktivitas antimikroba dari senyawa fenolik terkait dengan inaktivasi enzim seluler atau disebabkan olehperubahan permeabilitas membran. Tanin merupakan salah satusenyawa kimia yang termasuk dalam 
golongan polifenol yang diduga dapat mengikat salah satu protein membran yang dimiliki oleh bakteri dan apabila hal ini terjadi makadapat merusak ketersediaan reseptor pada permukaan sel bakteri sehingga mengganggu proses metabolisme sel tersebut (Pratiwi et al., 2013).
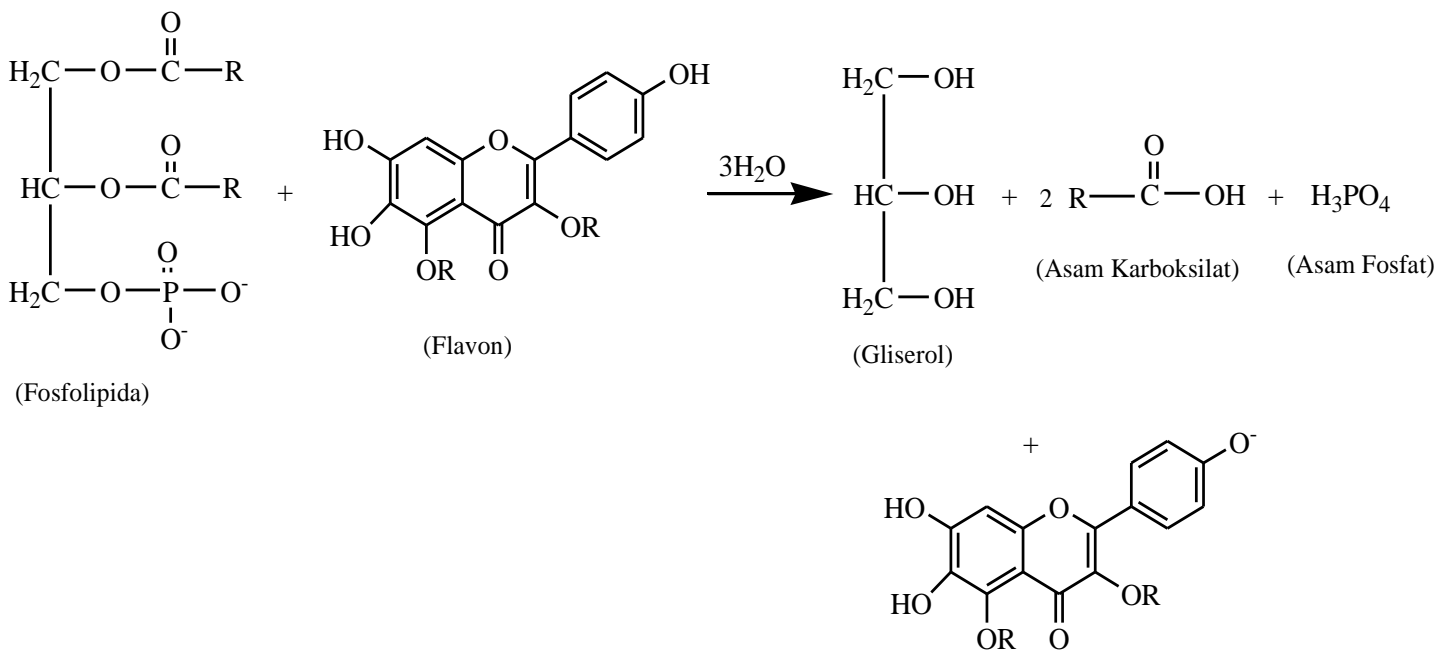

Gambar 1. Reaksi penguraian fosfolipida pada membran sitoplasma bakteri.

\section{KESIMPULAN}

Aktivitas antibakteri ekstrak metanol sarang lebah memiliki aktivitas tertinggi pada bakteri E. coli yaitu 3,80 mm pada konsentrasi $8 \times 10^{4} \mathrm{ppm}$, ekstrak etil asetat sarang lebah pada bakteri $S$. aureus yaitu 3,72 mm pada konsentrasi $8 \times 10^{4}$ ppm dan ekstrak n-heksan sarang lebah pada bakteri $E$. coli yaitu $16,10 \mathrm{~mm}$ pada konsentrasi $8 \times 10^{4} \mathrm{ppm}$. Semakin tinggi konsentrasi maka semakin besar pula daya hambat ekstrak terhadap pertumbuhan bakteri Staphylococcus aureus, Escherichia coli dan Pseudomonas aeruginosa.

\section{DAFTAR PUSTAKA}

Brehm-Strecher, B.F., and Johnson, E.A., 2003. Sensitization of Staphylococcus aureus and Escherichia coli to Antibiotics by the Sesquiterpenoids Nerolidol, Farnesol, Bisabolol, and Apritone, Antimicrobial Agents and Chemotherapy 47(10), 33573360. doi: 10.1128/AAC.47.10.3357-3360.2003.

Fitriana, I.N., 2013. Uji Aktivitas Antibakteri Ekstrak Etanol Daun Adas (Foeniculum vulgare Mill.) terhadap Staphylococcus aureus ATCC 6538 dan Escherichia coli ATCC 11229 secara IN VITRO, Tesis. Fakultas Kedokteran UMS, Surakarta.

Fratini, F., Cilia G., Turchi, B., and Felicioli, A., 2016. Beeswax: A Minireview of Its Antimicrobial Activity and Its Application in Medicine, Asian Pacific Journal of Tropical Medicine 9 (9), 839-843.

Huliselan, Y.M., Runtuwene, M.R.J., Wewengka, D.S., 2015. Aktivitas Antioksidan Ekstrak Etanol, Etil Asetat dan n-Heksan dari Daun Sesewanua (Clerodendron squamatum Vahl.), PHARMACON Jurnal Ilmiah Farmasi 4(3), 155-163. 
Lauma, S.W., Pangemanan, D.H.C., 2015. Uji Efektifitas Perasan Air Jeruk Nipis (Citrus aurantifolia $S$ ) Terhadap Pertumbuhan Bakteri Staphylococcus aureus Secara In Vitro, PHARMACON Jurnal Ilmiah Farmasi 4(4), 9-15.

Lutpiatina, L., 2015. Efektivitas Ekstrak Propolis Lebah Lelutut (Trigona spp) dalam Menghambat Pertumbuhan Salmonella typhi, Staphylococcus aureus dan Candida albicans, Jurnal Skala Kesehatan 6(1), 6-7.

Mandal, S., DebMandal, M., Pal, N.K., and Saha, K., 2010. Antibacterial Activity of Honey against Clinical Isolates of Escherichia coli, Pseudomonas aeruginosa and Salmonella enterica serovar typhi, Asian Pacific Journal of Tropical Medicine 3(12), 961-964. doi: 10.1016/S1995-7645(11)60009-6.

Munte, L., Runtuwene, M.R., and Citraningtyas, G., 2015. Aktivitas Antioksidan dari Ekstrak Daun Prasman (Eupatorium triplinerve Vahl.), PHARMACON Jurnal Ilmiah Farmasi 4(3), 41-50.

Naqvi, S.A.R., Mahmood, N., Naz, S., Hussain, Z., Sherazi, T.A., Khan, Z.A., Shahzad, S.A., Yar, M., Bukhari, I.H., Ahmad, M., and Mansha, A., 2013. Antioxidant and Antibacterial Evaluation of Honey Bee Hive Extracts using in Vitro Models. Jurnal Mediterranean Journal of Nutrition and Metabolism (3)6, 247-253. doi: 10.1007/s12349-013-0139-x.

Ngajow, M., Abidjulu, J., and Kamu, V.S., 2013. Pengaruh Antibakteri Ekstrak Kulit Batang Matoa (Pometia pinnata) terhadap Bakteri Staphylococcus aureus secara In vitro. Jurnal Mipa Unsrat Online 2(2), 128-132.

Pratiwi, D., Suswati, I., and Abdullah, M., 2013. Efek Anti Bakteri Ekstrak Kulit Jeruk Nipis (Citrus aurantifolia) terhadap Salmonella typhi secara In Vitro. Medika Jurnal Ilmu Kesehatan dan Kedokteran Keluarga 9(2), 110-115. doi: 10.22219/sm.v9i2.4139.

Putri, A.A.S., and Hidajati, N., 2015. Uji Aktivitas Antioksidan Senyawa Fenolik Ekstrak Metanol Kulit Batang Tumbuhan Nyiri Batu (Xylocarpus moluccensis). UNESA Journal of Chemistry 4(1), 37-42.

Rahman, M.M., Richardson, A., and Sofian-Azirun, M., 2010. Antibacterial Activity of Propolis and Honey against Staphylococcus aureus and Escherichia coli. African Journal of Microbiology Research 4 (16), 1872-1878.

Rand, E.E.du, Smit, S., Beukes, M., Apostolides, Z., Pirk, C.W.W., and Nicolson, S.W., 2015. Detoxification Mechanisms of Honey Bees (Apis mellifera) Resulting in Tolerance of Dietary Nicotine. Scientific Reports 5, 1-11. doi: 10.1038/srep11779.

Rizal, S., Dewi, H., and Utomo, T.P., 2015. Pengaruh Jenis Pelarut terhadap Aktivitas Antibakteri Ekstrak Daging dan Biji Buah Bintaro(Cerbera manghas L.). Jurnal Teknologi \& Industri Hasil Pertanian 20, 51-64.

Sholihah, J., 2013. Aktivitas Antibakteri dan Antioksidan Tiga Jenis Madu Hutan Indonesia, Skripsi, Fakultas Kehutanan IPB, Bogor.

Sulistyaningsih, R., Firmansyah, and Tjitraresmy, A., 2016. Uji Aktivitas Ekstrak Etanol Bayam Duri (Amaranthus spinosus) terhadap Bakteri Staphylococcus aureus dan Pseudomonas aeruginosa dengan Metode Difusi Agar. Farmaka 14(1), 93-102. 10.24198/jf.v14i1.8731.g4145. 
Wang, Y., Liu, Y., Li, G., and Hao, J., 2014. Porphyri-Based Honeycomb Films and Their Antibacterial Activity. Langmuir 30 (22), 6419-6426. doi: 10.1021/la501244s.

Yuliana, R., Sutariningsih, E., Santoso, H., Hendarto, K.A., and Riendrasari, S.D., 2015. Daya Antimikroba Sarang Lebah Madu Trigona spp terhadap Mikrobia Patogen. Biodedukasi 8(1), 67-72. 